
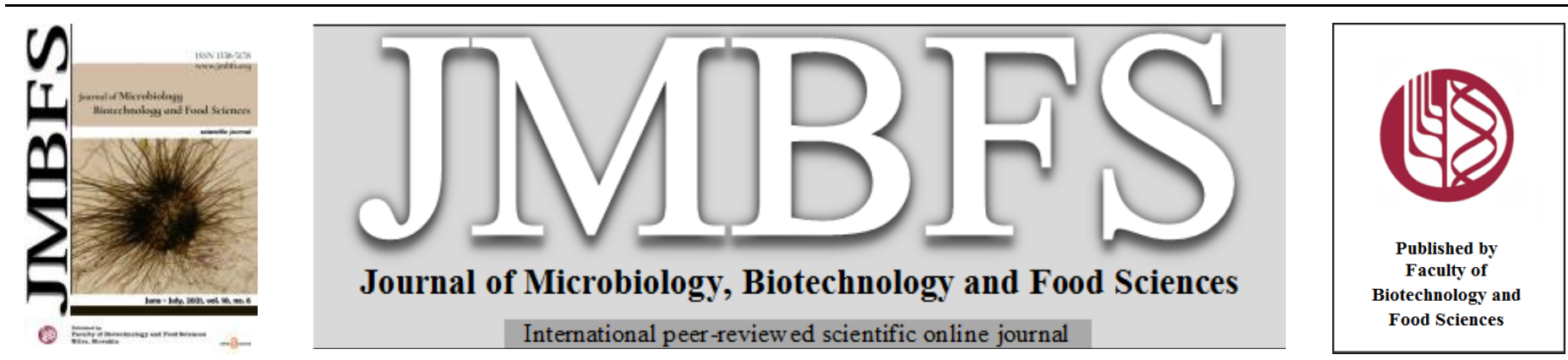

\title{
REVIEW OF HERBAL MEDICINE AS A NATURAL GIFT AND PROPER RIFLE TO OVERCOME PATHOGENIC INFECTIONS
}

\section{Mohammad Ali Shariati ${ }^{1, *}$, Elena Zakabunina ${ }^{2}$, Vladimir Ermolaev ${ }^{3}$,Alexey Ilmushkin ${ }^{l}$, Ekaterina Sepiashvili ${ }^{1}$, Vera Simonova ${ }^{l}$, Sergey Okhramenko ${ }^{1}$, Lilya Ponomareva ${ }^{l}$, Natalia Bratishko ${ }^{I}$, Ruslan Maksyutov ${ }^{I}$, Elena Melnikova ${ }^{I}$, Viktor Konovalov ${ }^{I}$, Viktor Klimov ${ }^{1}$, Godswill Ntsomboh Ntsefong ${ }^{4}$}

\author{
$\operatorname{Address}(e s)$ : \\ ${ }^{1}$ K.G. Razumovsky Moscow State University of technologies and management (the First Cossack University), Moscow, Russia. \\ ${ }^{2}$ Russian State Agrarian Correspondence University143907, Moscow region, Balashikha, Russian Federation . \\ ${ }^{3}$ T.F. Gorbachev Kuzbass State Technical University, Kemerovo, Russian Federation. \\ ${ }^{4}$ Department of Plant Biology, Faculty of Science, University of Yaounde 1, Cameroon.
}

*Corresponding author: shariatymohammadali@mail.com

https://doi.org/10.15414/jmbfs.4840

\section{ARTICLE INFO}

Received 11.11.2020

Revised 11. 4. 2021

Accepted 14. 4. 2021

Published 1. 6. 2021

\section{Review}

open $\partial_{\text {ACCESS }}$

\section{ABSTRACT}

Plants are used for several purposes in different industries like pharmacy, food, cosmetic etc. Some of them like spices have antimicrobial and antioxidant properties due to their capacity to produce secondary metabolites. In recent decade, the emergence of novel diseases, epidemics, and even pandemics along with the ability of a large group of pathogens to adapt against available antibiotics have caused scientists to explore natural and new sources of antimicrobial agents. These natural antimicrobial compounds are broadly used to design innovative drugs, in particular for those pathogenic strains that have been resistant to existing antibiotics in market. This review represents some of the recent findings on the antimicrobial activities of medicinal herbs.

Keywords: antibacterial potential, antibiotics, bacterial infections, medicinal plants, resistance

\section{INTRODUCTION}

The use of herbal drugs to treat a large number of diseases could be traced back to over 5 thousand years. Mankind started to explore components with acceptable therapeutic potentials as soon as they began to identify them (Nweze et al., 2004; Vineela and Elizabeth, 2005; Pavithra et al., 2010; Shinwari and Qaisar, 2011; Shakya and Shukla, 2011; Alzoreky and Nakahara, 2003; Clementi et al., 2014; Zaheer et al., 2021; Sultana et al., 2021; Khouchlaa et al., 2021) The term "medicinal herbs" refers to not only those used as sedative agents but also those that could be incorporated as flavors, drinks, sweeteners, natura pigments, herbicides as well as cosmetic products (Omidbeigi, 1997). Medicina herbs are composed of adapted antimicrobial systems through production of secondary metabolites in their cells (Kim et al., 1995; Ahmad and Beg, 2001; Alagesaboopathi, 2011).

In folklore medicine, herbal drugs are used to mitigate the risks of pathogenic infections. Awareness of side effects involved in the application of chemica drugs might shift people's interest towards more natural products to avoid such health issues. Beside side-effects, the incidence of multi resistant pathogenic strains to available antibiotics is considered to be another driving force towards finding a proper candidate to overcome resistant strains.

Developments in chemical sciences and the discovery of complicated synthetic organic systems have led to the outreach of pharmacology. On the basis of WHO report, it is estimated that 80 percent of population worldwide are positive towards medicinal herbs and conventional medication methods applied by folk healers. Plants used in such cases contain different constituents that allow them to be used as a part of food supplements, phyto-pharmaceuticals, novel drugs and many more (Farnsworth and Loub, 1983; Hammer et al., 1999; Mukherjee, 2002; Janovska et al., 2003; Bodeker et al., 2005; Ahmed et al., 2020).

From the economical viewpoint, plants are considered to be a proper revenue source due to their biologically active secondary metabolites such as phenolic compounds with different phyto-pharmaceutical activities (Stary and Hans, 1998). It is almost popularized the empirical application of medicinal plants and most countries have organized their facilities to contribute in screening programs of medicinal plants in order to explore and stabilize their antimicrobial activities in primary health care (Baba-mousa et al., 1999). Like most organisms, medicinal herbs are influenced by environmental conditions that cause changes in appearance, flower, leaves, fruits, and in particular natural composition profiles which can even alter the antimicrobial activities (Balandrin et al., 1985). Currently, medicinal plants are collected either in small quantities for domestic purposes or in large scales by factories to valorize them by increasing the number of components that could be extracted and pharmaceutically employed (Bhowmik et al., 2010).

Such compounds called phytochemicals are suggested as one of the diseasefighting strategies (Abu-Izneid et al., 2020; Imran et al., 2021). Phytochemicals are secondary metabolites produced by medicinal drugs that can be prescribed directly to limit the microbial growth, or can be used as leading compounds against pathogenicity (Jahn et al., 1986; Jabeen et al., 2008).

The potentials of using herbal drugs as antimicrobial agents have drawn researchers' attention recently, as reflected by the number of published studies on the introduction of superseded anti-microbial agents. The main scores involved in the application of herbal drugs might be their availability, affordability in production, being nonhazardous and environmentally friendly (Soldati, 1997; Martino et al., 2002; Shahidi Bonjar et al., 2004; Joseph et al., 2008; Pitchai et al., 2010).

Most plant-derived secondary metabolites screened by laboratory techniques, including in vitro methods, have been evaluated for possible antimicrobial activity, which in turn leads to providing a platform to make proper selection of crude extracts for further pharmacological researches (Mathekaga and Meyer, 1998; Alli smith, 2009). Table 1 summarizes some of the recently published literature on the application of medicinal herbs against pathogens.

Secondary metabolites are glycosides, saponins, flavonoids, steroids, tannins, alkaloids, terpenes and their potentials to combat divergent pathogenic microorganisms is outstanding (Davis, 1994; Lopez et al., 2001; Anthara and Amla, 2012).

With no doubt, antibiotics are one of the most leading discoveries achieved in the 20th century. Nevertheless, less than half of infectious diseases are being medicated using them (Preethi et al., 2010; Sharma, 2011). This might arise from the consecutive years of pathogenic outbreaks and their widespread along with successive and misuse of antibiotics. Therefore, the incidence of multi-drug resistant pathogenic strains shifting towards a global therapeutic issue (Dean and Burchard, 1996; Enne et al., 2001; Westh et al., 2004).

One major challenge that scientists face is how to control drug resistant pathogenic strains with less vulnerability to antibiotics. This has led to the exploration of innovative drug sources with lower side effects and reduction of 
adulteration (Silver, 1993; Sieradzki et al., 1999; Debasis, 2014). This review aims at presenting a perspective on previous and recently findings on the application of medicinal herbs to overcome infections caused by pathogens as a contribution towards introducing herbal drugs as an innovative solution to mitigate the incidence of resistant pathogenic strains.

\section{Bioactive components derived from medicinal herbs}

One characteristic discriminating plants as medicinal herbs is the metabolic mechanisms of secondary metabolite production as final products that can be applied to treat various maladies. Some of the natural secondary metabolites in medicinal herbs are presented in the next section.

\section{Alkaloids}

Alkaloids are defined as chemical compounds with at least one nitrogen atom in a heterocyclic ring. Biologically, alkaloids are nitrogen components produced through synthetic methods or found in naturally occurring forms in plants or animals. Most alkaloids are crystalized components which could combine with acids and produce mineral salts.

These components are explored either in free form, salts or $\mathrm{N}$-oxides and mostly accumulated in storage tissues including roots, stems, flowers, seeds and active photosynthetic tissues. The production rate of alkaloids wane as the end of autumn approaches. The amount of alkaloids constitutes 10 percent of dry weight of epidermal tissues like cocaine, colchicine, as well as steroidal alkaloids like nicotine. The stated alkaloids are considered to be the first plant defending system.

The structure of alkaloids varies with respect to the synthesizing and accumulation location, the stage of growth, their life cycles, as well as plant sections. After addition of sodium bicarbonate and/or ammonium, alkaloids would be precipitated and extracted using organic solvents (Torras-Claveria $\boldsymbol{e}$ al., 2014). Up to now, more than 5000 alkaloids have been detected in different parts of plants like pomegranate root, poppy capsule, datura leaves, and cannabis fruit. Interestingly, alkaloids have effects on nerve system and have sedative properties. They also have anti-cancer activities, stimulating impact like caffeine in coffee, and anti-parasite activity like alkaloids present in pomegranate roo (Torras-claveria et al., 2014). Figure 1 depicts some of the alkaloids.

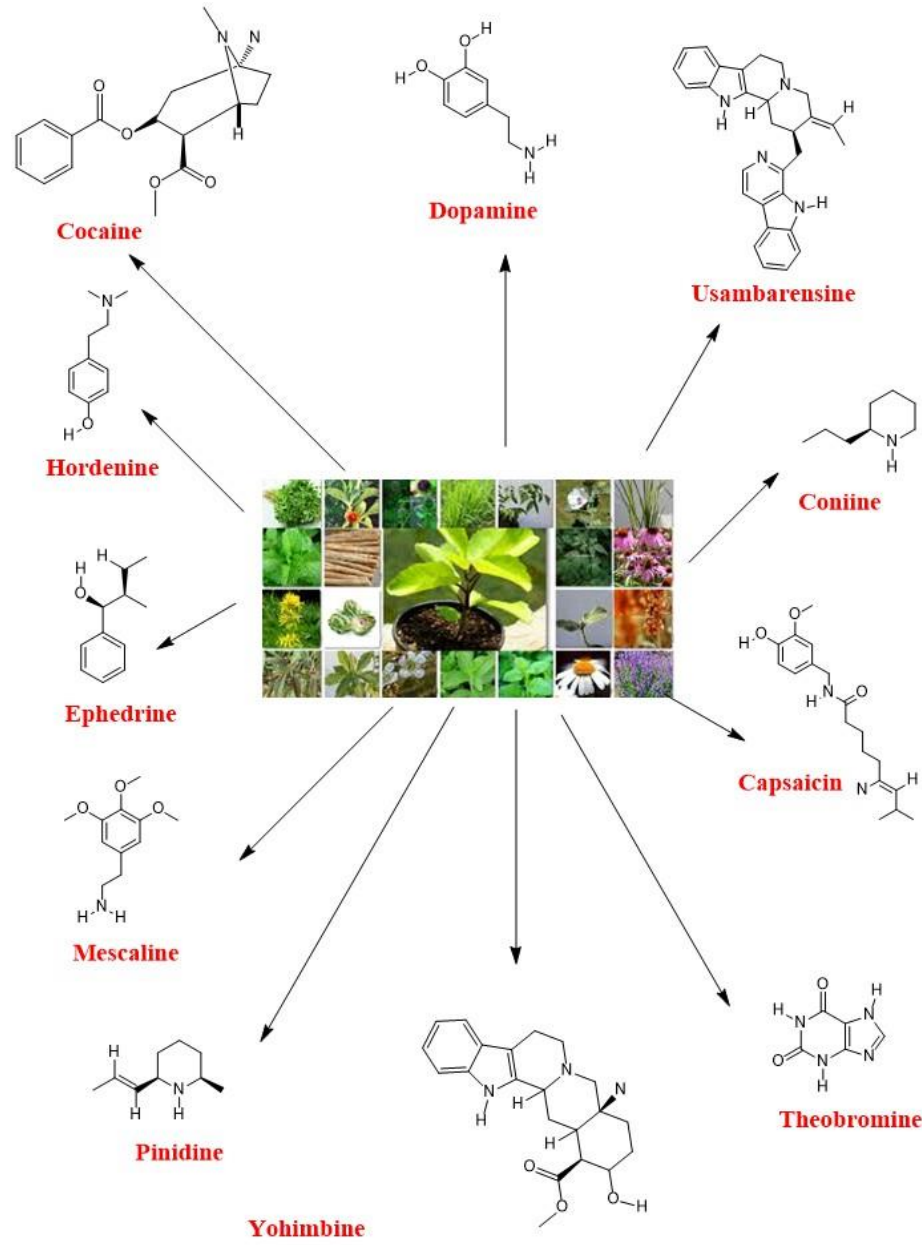

Figure 1 Selected alkaloids in medicinal herbs

\section{Flavonoids}

Flavonoids are plant-based compounds with heart healing properties. The term "flavonoids" represents a large group of phenolic compounds that are derived from phenyl propanoid with a-Fifteen-Carbone atom structure. These compounds carry out various functions in plants such as plant pigmentation and UV filtration in plants. They could also perform some functions in the human health care system; increasing antimicrobial strength, mitigating oxidation through chelating ions such as iron and copper, controlling cancer cells within gene expression, improving immune system, playing anti-viral, anti-inflammation, anti-allergic, and anti-mutation and even anti-hepatitis roles in the body (Kumar and Pandy, 2013).

\section{Glycosides}

Glycosides are secondary metabolites composed of a simple sugar like glucose which is linked to another functional compound by means of glycosidic bond Glycoside are classified on the basis of glycone type, type of glycosidic bond as well as glycone.

\section{Bitter compounds}

Pharmacologically, bitter components are related to terpenic group which leads to the release of azolene and other glycosides with different chemical structures (Aliani and Eskin, 2017)

\section{Terpenes}

Terpenes, the main constituents of essential oils, are built of carbohydrate. Some of the terpenes contain oxygen included components like alcohol, aldehyde or ketones, but are still categorized as terpenes. Various classifications of terpenes are as below (Breitmaier and Eberhard, 2006):

-Hemi-terpene: They are made of a unit of isoprene. Isoprene is considered merely to be a hemiterpene. However, some of the hemi-terpenes include oxygen like isovaleric acid.

-Mono-terpenes: composed of two units of isoprene. One of the alcoholic monoterpene is geranyl.

-Sesquiterpene: contains 3 units of isoprene like furanosyl.

-Diterpene: made of 4 units of isoprene and are derived from gerany pyrophosphate.

-Sesterpene: made of 5 isoprene

-Triterpene: made of 6 units of isoprene. Squalene, the main part of isoprene of shark liver oil, is a member of this group.

-Tetraterpene: made of 8 units of isoprene such as no ring Lycopene

-Poly-terpene: made of a long chain of isoprene like natural rubber.

\section{Essential Oils}

Essential oils are recognized as liquid components at ambient temperature, solid at cold temperatures, and soluble in organic solvents like chloroform, acetone (Reddy, 2019). They contain different micro-constituents (Figure 2).

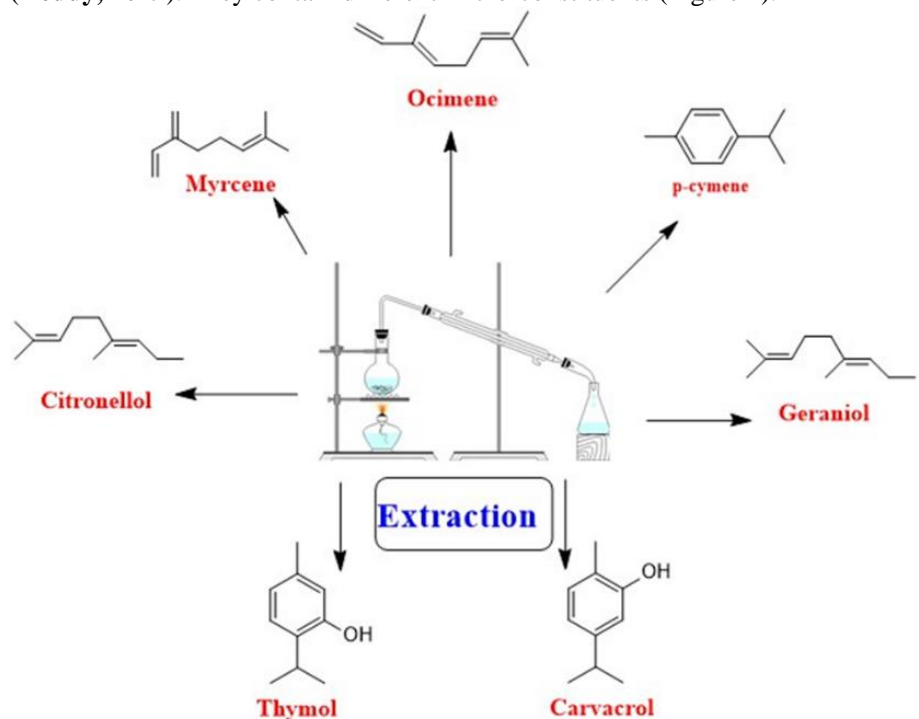

Figure 2 Selected micro-constituents that are presented in essential oils.

\section{Antimicrobial properties of essences}

Since essential oils have hydrophobic properties, they could easily diffuse in lipid membranes of bacteria or mitochondria, resulting in interference of efflux pump mechanism which causes the leakage of vital molecules and ions from bacteria, 
ultimately leading to death (Cox et al., 2000). The same mechanisms also lead to death of fungi cells (Ultee and Smid, 2000). The position of hydroxyl group in essence determines how much antimicrobial activity might a compound depict. (Dorman and Deas, 2000).

\section{Effective factors on antimicrobial activities of essential oils}

There are several factor affecting antimicrobial activity of essential oils; they are categorized into 2 groups, internal or intrinsic properties of food such as structure, water content, protein, carbohydrate, salt and $\mathrm{pH}$, and external factors including temperature, light, atmosphere and type of packaging (Tassou et al. 1995). Essential oils portray hydrophobicity which allow them to partition into membranes and therefore increase antimicrobial activity. Unlike fat and protein, carbohydrates have no protecting efficacy on bacteria (Mejlholm and Dalgaard, 2002). Physical structure of food has significant effect on antimicrobial activity. Thus essential oils are more effective against pathogens in liquid food media such as milk, compared to solid structures like meat (Skandamis et al., 2000).

\section{Mechanisms of action}

Antimicrobial activity of extracted compounds has been evaluated individually in labratories. However, the obtained results from various studies have been contradictory and this makes their comparing and judgement effortful (Mann and Makham, 1998; Manou et al., 1998; Skandamis et al., 2001). Besides, it is not still clarified whether the applied methods are targeting to evaluate antimicrobial activity and/or to mitigate the microbial growth. Antimicrobial assessments measure the diameter of inhibited growth area around inoculated paper-discs with an antimicrobial compound on agar considering the following: inhibition of bacterial growth on agar surface with diffused antimicrobial components; and minimum inhibition concentration of antimicrobial activity in liquid environment.

In addition, three important factors which might influence the results of experiments are:

-the combination of parameters in regard to test samples; -the type of microorganisms and their growth conditions -the applied methods in counting of live bacteria.

Most studies like diffusion disc or turbidimetry are on the basis of growth inhibition. The uniform distribution of essential oils in agar is of great importance. Besides uniformity, the present of bioactive compounds are also effective on the results; in lower concentrations, bioactive compounds could act in antagonistic or synergistic manner.

Diversity in the antimicrobial reactions of the components arise from their simple form or their use in combination with complexes (Stechini et al., 1993, 1998) Considering the type of reaction, various determination methods are used Turbidimetry is a non-destructive and inexpensive method but has low sensitivity. This method could help with determination of upper section of growth curve; therefore, to correlate the results with the counting of live cells in agar, the method needs to be calibrated.

Changes in absorbance manifest the only response when the total count is 106 $107 \mathrm{CFU} / \mathrm{ml}$. The physiological conditions of cells (intact or destroyed), and oxidation level of essential oils could be effective on the absorbance level. Despite total count techniques, impedance methods are based on monitoring of microbial metabolism. Impendence techniques are employed to screen destroying activities and to assess growth kinetics in mathematical models (Lachowicz $\boldsymbol{e}$ al., 1998).

Conventional techniques depend on the number of live cells counted in plates. However, such techniques are time-consuming and require high-costs. Minimum inhibition concentration (MIC) is determined through consecutive dilution of broth by plate count (Lambert and Pearson, 2000). This requires increasing the monitoring of compounds and microorganisms (Lambert and Pearson, 2000). It could favor simultaneous evaluation of single or several preservatives, and consequently determination of MIC based on mathematical models.

\section{Food applications}

Microorganisms are considered to be one of the oldest and successful creatures in our planet, due to their high adapting and survival potentials compared to other organisms that are annihilated after a while. Subjecting pathogenic microbes to antibiotics produced from other microorganisms (the latter introduced as probiotics) could lead to the development of resistant mechanism; therefore, it is not surprising that mankind encourages the ever growing problematic challenges in regards to the control of microbes (Opal et al., 2000).

It is estimated that $10-20$ percent of plant population could be used as drugs to serve health care processes like isolation, purification and extraction of herbal drugs which may lead to the production of a group of components with biological activities (Naczk and Shahidi, 2006; Kibwage et al., 2006).

Among the extracted components, some of them like essential oils have antimicrobial activity. In-vivo techniques are used to evaluate antimicrobia activities of essential oils (Nychas and Tassou, 2000). Some of the ambient conditions are also critical for the efficacy of antimicrobial lethality like the presence of oxygen. For instance, Paster and coworkers found that essential oil of thyme is active against $\mathrm{S}$. aureus and $S$. entrididis in aerobic and anaerobic conditions (Paster et al., 1990). In addition, essential oil of oregano was more effective in the presence of $41 \% \mathrm{CO} 2,31 \%$ oxygen, and $31 \%$ nitrogen compared to air permeable packs. In another study, essential oil of oregano was shown to have antimicrobial activity against $\mathrm{S}$. aureus and $S$. entridids at modified atmosphere packaging at $1^{\circ} \mathrm{C}$, and $S$. putrefacins and $P$. phosphurum in treated cod fish with essential oil of oregano (Tassou, 2002).

Essential oils are mostly combined with protein, fat, sugar and salt, therefore only a low concentration of essential oil (EO) which remains free could exhibit antimicrobial activity. External factors like temperature limit antimicrobial activity of EO (Davidson, 1997). Physiological properties of bacteria grown in food matrices differ remarkably from those grown in different liquid cultures Such differences could be due to the following reasons: population, availability of nutrients, availability of oxygen, and the accumulation in final products.

Mechanism of action

The mechanism of action of essential oils depends on the concentration (Prindle and Wright, 1977). Lower concentrations prevent energy related enzymes while higher amounts cause precipitation of proteins. Nonetheless, it is still under question whether the damages to membranes are associated with the amount of antimicrobial compounds contacting the cell membrane or their effects on cell injuries leading to cell death. Solutions of trace elements like iron have negative effects on essential oils. Hence, one proper way to inhibit microbial growth might be limitation of cell availability to such ions like irons. Furthermore, ferrous ion could combine with phenolic compounds and indirectly lead to cell destruction owing to oxidative stress (Friedman and smith, 1984). Aldehyde groups in some animal and plant tissues react with main base and prevent biosynthesis of the cell wall (Patte, 1996). Phenolic compounds, essential oils and phytoalexin are mostly active to inhibit microbial growth, rather than exhibition of toxic effects (Tokutake et al., 1992). Leakage of cell membrane might not directly inhibit microbial growth, but decelerate the metabolic processes of meiosis (Kubo et al., 1985). Behavior of essential oils in destroying gram positive or gram negative bacterial could be considered as another critical reason.

Compared to gram negative bacteria, gram positive ones are more sensitive (Dabbah et al., 1970; Shelef et al., 1980, 1983; Farag $\boldsymbol{e t}$ al., 1989), yet various inhibiting mechanisms could be found among gram negative bacteria. For instance, $E$. coli is more resistance than $S$. flurescence or $C$. marcescence when exposed to essential oils of rosemary, garlic and thyme (Farag et al., 1989). Mutated E. coli and S. aureus are resistant against essential oils of pine (Moken et al., 1997).

In recent times, scientific results have shown that pharmaceutically extracted compounds belong to phenolic compounds, vitamins and tannins with striking antioxidant activity (Suffredini $\boldsymbol{e t}$ al., 2004). Many papers have been published on the basis of the possible antimicrobial activities of medicinal herbs against gram positive and gram negative bacteria (Evans et al., 2002). Both negative and positive gram bacteria could be responsible for various ailments. For instance, gram (+) bacteria like Staphylococcus aureus could create wound infection, toxic shock syndrome and food poisoning (Benayache et al., 2001) while gram (-) bacteria like $\mathrm{E}$. coli is the main reason of diarrhea in human, and also can cause coleocycystis or septicaemia (Benhassaini et al., 2003). Among recently detected infections, those caused by Methicillin-resistant Staphylococcus aureus (MRSA) are of great importance owing to their high adaptability in overcoming almost all clinically antibiotics available in the market (Adwan et al., 2009). As previously stated, a problematic issue in destroying the pathogens might be their adaptability to antibiotics and application of herbal medicine might be a superior candidate to control them.

Pathogens employ various mechanisms to control antibiotics like specialized efflux systems. One of the other pathogen that is resistant to different available antibiotics, $P$. aeroginosa enjoys the mentioned strategy to overcome antibiotics (Elbashiti et al., 2011). Another mechanism to protect pathogens against antibiotics is the production of extended-spectrum $\beta$ Lactamases-M (ESBLs) enzymes (Darwish and Aburjai, 2010).

\section{CONCLUSION}

Generated flavors through application of essential oils, presence of the aromatic components in medicinal herbs together with necessities to high-cost methods in order to find antimicrobial agents among bioactive components have limited the use of essential oils as antimicrobial agents. Application of such compounds should be under an accurate selection system along with evaluation of their antimicrobial potentials in the least concentrations. Incorporation of essential oils to food formulae or using them, either alone, in combination with other chemica preservatives, could favor their synergistic effects in fighting against various infections and spoilage. The prospect of synergistic effect of the simultaneous application of various spices and medicinal herbs in designing new drugs and replacing chemical drugs with such sources would be of great importance in future research studies. 
Table 1 Some recently published studies on the application of herbal drugs in fighting against pathogens

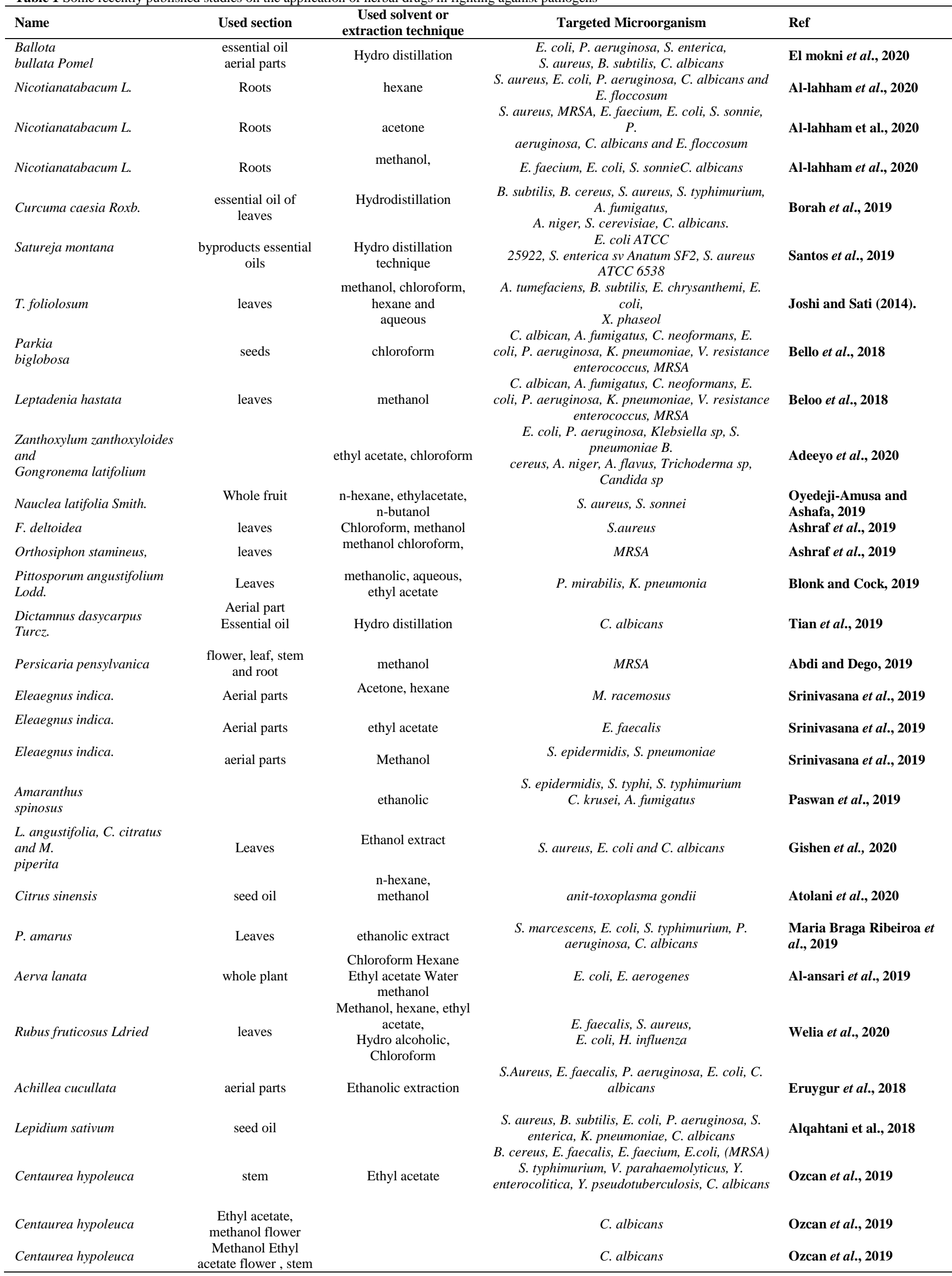


Centaurea hypoleuca acetate flower, stem

Centaurea hypoleuca Flower Ethanol Methanol Ethy acetate

Ethanol

abyssinia A.Br. Root

Root aqueous

abyssinia A.Br.

Hydnora

abyssinia A.Br.

Leucas aspera (Willd.)

Solanum incanum $L$.

Harrisonia abyssinica Oliv.)

Harrisonia abyssinica Oliv.)

Veronicastrum latifolium ( $V$. latifolium)

plant oils; Tea tree.

Cinnamon,

Rosemary, Cactus,

Lavender, Basil, Lemon,

Thyme, Parsley, Almond and

Lupine.

Foeniculum vulgare Mill.

Black pepper

Melissa officinalis

Essential oil of aerial part

Water-distillation

Rosa damascena

Rumex species-

Habanero Chili

Pollen

Hypoxis hemerocallidea

Artemisia annua L

Pomegranate

Diospyros lotus

Roots
$V \cdot$ parahaemolyticus

Ozcan et al., 2019

B. cereus

Ozcan et al., 2019

Guadie et al., 2020

Guadie et al., 2020

E. coli, S. typhimurium

E. feacalis, E. coli, S. typhimurium

E. coli, E. feacalis and S. aureus

E. coli, E. feacalis and S. typhimurium E. coli, $S$.

typhimurium, $S$. aureus

E. feacalis, E. coli, $S$.

typhimurium, $S$. aureus.

S. aureus, B. subtilis. E.

Coli, P. aeruginosa, A. baumannii, C. albicans

S. aureu, S. epidermidis, C. acnes

Esmaeil et al., 2019

C. albicans, B. cereus

$S$. aureus, B. cereus, and S. faecalis

Botrytis cinerea, Penicillium expansum and Rhizopus stolonifer.

Erwinia, S. aureus, C. violaceum, carotovora, B. subtilis, $P$. aeruginosa and E. coli, C. violaceum

Antimicrobial activity

Salmonella enterica subsp. Typhimurium (33\%) and Yersinia enterocolitica $(16.65 \%)$

Antimicrobial activity Anti-HIV

Anti-HIV activity

M. R. S. aureus S. entrididis L. monocytogenese Paeroginosa

$$
\text { E coli }
$$

E. coli, S.aureus, B. subtilis, K. pneumonia S. epidermis
Guadie et al., 2020

Guadie et al., 2020

Guadie et al., 2020

Guadie et al., 2020

Guadie et al., 2020

Yin et al., 2019

Ilić et al., 2019

Shityakov et al., 2019

El Ouadi et al., 2017

Akram et al., 2019

Prakash Mishra et al., 2018

Hleba et al., 2015

Kostic et al., 2020

Laila et al., 2019

Laila et al., 2019

Pirzadeh et al., 2020
Rauf et al., 2020

\section{REFERENCES}

Abu-Izneid, T., Rauf, A., Shariati, M.A., Khalil, A.A., Imran, M., Rebezov, M., Uddin, M.S., Mahomoodally, M.F., \& Rengasamy, K.R.R. (2020). Sesquiterpenes and their derivatives-natural anticancer compounds: An update. Pharmacological Research, $161, \quad 105165$ https://doi.org/10.1016/j.phrs.2020.105165.

Abdi, R.D., \& Dego, O.K. (2019). Antimicrobial activity of Persicaria pensylvanica extract against Staphylococcus aureus. European Journal of Integrative Medicine, 29, 100921.

Adeeyo A.O., Odelade, K., Msagati, T.A.M., \& Odiyo, J.O. (2020). Antimicrobial Potencies of Selected Native African Herbs against Water Microbes. Journal of King Saud University. https://doi.org/10.1016/j.jksus.2020.03.013

Adwan, G., Abu-Shanab, B., \& Adwan, K. (2009). In vitro Interaction of Certain Antimicrobial Agents in Combination with Plant Extracts against Multidrugresistant Pseudomonas aeruginosa Strains. Middle-East Journal of Scientific Research, 4 (3), 158-162. https://doi.org/10.1016/s1995-7645(10)60064-8

Ahmad, I., \& Beg, A.Z. (2001). Antimicrobial and phytochemical studies on 45 Indian medicinal plants against multiple drug resistant human pathogens. Journa of Ethanopharmacology, 74, 113-123. https://doi.org/10.1016/s0378 8741(00)00335-4

Ahmed, S., Hasan, M.M., Heydari, M., Rauf, A., Bawazeer, S., Abu-Izneid, T., Rebezov, M., Shariati, M.A., Daglia, M., \& Rengasamy, K.R. (2020), Therapeutic potentials of crocin in medication of neurological disorders. Food $\begin{array}{llll}\text { and Chemical } & \text { Toxicology, } & 145, & 11739 .\end{array}$ https://.doi.org/10.1016/j.fct.2020.111739

Akram, M., Riaz, M., Munir, M., Akhtar, N., Zafar, S., Jabeen, F., Shariati, M.A., Riaz, Z., Atlaf, S.H., Daniyal, M., Zahid, R., \& Zahid Khan, F.S. (2020) Chemical constituents, experimental and clinical pharmacology of Rosa $\begin{array}{lllll}\text { damascena: a literature } & \text { review. } 72 & \text { (2): 161-174 }\end{array}$ https://doi.org/10.1111/jphp.13185

Alagesaboopathi, C. (2011). Antimicrobial Potential and Phytochemical

Screening of Andrographis Affinis Nees an Endemic Medicinal Plant from India.
International Journal of Pharmacy and Pharmaceutical Sciences, 3 (2), 157159.

Alqahtani, F.Y., Aleanizy, F.S., Mahmoud, A.Z., Farshori, N.N., Alfaraj, R., Alsheddi, E.S., Alsarra, I.A., \& Centaurea hypoleuca, D.C. (2019). Chemical composition and antimicrobial, antioxidant, and anti-inflammatory activities of Lepidium sativum seed oil. Saudi Journal of Biological Science, 26 (5), 10891092. https://doi.org/10.1016/j.sjbs.2018.05.007

Al-Ansari, M., Al-Humaid, L.A., Vijayaraghavan, P., Ravindran, B., Chang, S.W., Agastian, P., Rathi, M.A., \& Balamuralikrishnan, B. (2019). Identification of phytochemical components from Aerva lanata (Linn.) medicinal plants and its in-vitro inhibitory activity against drug resistant microbial pathogens and antioxidant properties. Saudi Journal of Biological Sciences, 26, 1129-1133. https://doi.org/10.1016/j.sjbs.2019.02.010

Al-Lahhama, S., Sbieh, R., Jaradat, N., Almasria, M., Mosa, A., Hamayela, A., \& Hammada, F. (2020). Antioxidant, antimicrobial and cytotoxic properties of four different extracts derived from the roots of Nicotianatabacum L. European $\begin{array}{llll}\text { Journal of Integrative } \quad \text { Medicine, } & 33, & 101039 .\end{array}$ https://doi.org/10.1016/j.eujim.2019.101039.

Alli Smith, Y.R. (2009). Determination of chemical composition of Sennasiamea (Cassia leaves). Pakistan Journal of Nutrition, 2009;8(2):119-121. https://doi.org/10.3923/pin.2009.119.121

Alzoreky, N.S., \& Nakahara, K. (2003). Antibacterial activity of extracts from some edible plants commonly consumed in Asia. International Journal of Food Microbiology, 80, 223-30. https://doi.org/10.1016/s0168-1605(02)00169-1

Anthara, S., \& Amla, B. (2012). Evaluation of antimicrobial activity of different solvent extracts of medicinal plant: Melia Azedarach L. International Journal of Current Pharmaceutical Research, 4(2), 67-73.

Aono, R., Ito, M., Horikoshi, K. (1997). Measurement of cytoplasmic pH of the alkaliphile Bacillus lentus C-125 with a fluorescent pH probe. Microbiology, 143 2531-2536. https://doi.org/10.1099/00221287-143-8-2531

Ashraf, K., Halim, H., Meng Lim, S., Ramasamy, K., \& Sultan, S. (2019). In vitro antioxidant, antimicrobial and antiproliferative study of four different extracts of Orthosiphon stamineus, Gynura procumbens and Ficus deltoidea 
Saudi Journal of Biological Sciences. doi: Atolani, O., Adamu, N., Oguntoye, O.S., Zubair, M.F., Fabiyi, O.A., Oyegoke, R.A., Adeyemi, O.S., Areh, E.T., Tarigha, D.E., Kambizi, L., \& Olatunji, G.A (2020). Chemical characterization, antioxidant, cytotoxicity, Anti-Toxoplasma gondii and antimicrobial potentials of the Citrus sinensis seed oil for sustainable cosmeceutical production. Heliyon, 6 (2), e03399. https://doi.org/10.1016/j.heliyon.2020.e03399

Balandrin, M.F., Klocke, J.A., Wurtele, E.S., \& Bollinger, W.H. (1985) Natural plant chemicals: sources of industrial and medicinal materials. Science, 228 , 1154-1160. https://doi.org/10.1126/science.3890182

Benayache, S., Benayache, F., \& Benyahia, S. (2001). Leaf Oils of some Eucalyptus Species Growing in Algeria. Journal of Essential Oil Research, 13, 210-213. https://doi.org/10.1080/10412905.2001.9699668.

Benhassaini, H., Enabderrahmane, K., Chi, K. (2003). Contribution to the assessment of the antiseptic activity of essential oils and oleoresin of Pistacia tia Atlas on some microbial sources: Candida albicans (ATC 20027), Candida albicans (ATCC 20032) and Saccharomyces cerevisiae: ethnopharmacology, 30, 38-46.

Bello, O.M., Ibitoye, T., \& Adetunji, C. (2019). Assessing antimicrobial agents of Nigeria flora. Journal of King Saud University, 31 (4), 1379-1383. https://doi.org/10.1016/j.jksus.2018.04.017

Bhowmik, D., Chiranjib, Yadav, J., Tripathi, K.K., Sampath Kumar, K.P. (2010). Herbal Remedies of Azadirachta indica and its Medicinal Application. Journal of Chemical and Pharmaceutical Research, 2(1), 62-72.

Bodeker, C., Bodeker, G., Ong, C. K., Grundy, C. K., Burford, G., \& Shein, K. (2005). WHO Global Atlas of Traditional, Complementary and Alternative Medicine. Geneva, Switzerland: World Health Organization.

Borah, A., Paw, M., Gogoi, R., Loying, R., Sarma, N., Munda, S., Pandey, S.K., \& Lala, M. (2019). Chemical composition, antioxidant, anti-inflammatory, antimicrobial and in-vitro cytotoxic efficacy of essential oil of Curcuma caesia Roxb. leaves: An endangered medicinal plant of North East India. Industrial Crops \& Products, 129, 448-454. https://doi.org/10.1016/j.indcrop.2018.12.035 Breitmaier, E. (2006). Terpenes: Flavors, Fragrances, Pharmaca, Pheromones John Wiley \& Sons. pp. 1-13. ISBN 978-3527317868.

Baba-Moussa, F., Akpagana, K., Bouchet, P. (1999). Antifungal activities of seven West African Combretaceae used in traditional medicine. Journal of Ethnopharmacology, $66 \quad$ (3): $\quad 335-8 \quad$ https://doi.org/10.1016/s03788741(98)00184-6

Burapadaja, S., \& Bunchoo, A. (1995). Antimicrobial activity of tannins from Terminalia citrina. Planta Medica. 1995; 61: 365-366. Burapadaja S, Bunchoo A. Antimicrobial activity of tannins from Terminalia citrina. Planta Medica, 61, 365-366.

Clementi, E.A., Marks, L.R., Roche Hakansson, H., \& Hakansson, A.P. (2014) Monitoring changes in membrane polarity, membrane integrity, and intracellular ion concentrations in Streptococcus pneumoniae using fluorescent dyes. Journal Visualized Experimental, 84, 1-8. https://doi.org/10.3791/51008.

Cox, S. D., Mann, C. M., Markham, J. L., Bell, H. C., Gustafson, J. E., Warmington, J.R., \& Wyllie, S.G. (2000). The mode of antimicrobial action of essential oil of Melaleuca alternifola (tea tree oil). Applied Microbiology, 88: 170-175. https://doi.org/10.1046/j.1365-2672.2000.00943.x.

Davis, J. (1994) Inactivation of antibiotics and the dissemination of resistance genes. Science, 264 (5157), 375-382. https://doi.org/10.1126/science.8153624.

Dean, D. A., \& Burchard, K. W. (1996). Fungal infection in surgical patients American Journal of Surgery, 171, 374-382. https://doi.org/10.1016/s00029610(97)89647-x

Debasis M (2014) Antibacterial studies of the polymeric phenolic Schiff bases containing aminothiazole moiety. International Journal of Research in Pharmaceutical and Nano Sciences, 3(3): 215 - 221.

Dorman, H. J. D., \& Deans, S. G. (2000). Antimicrobial agents from plants: antibacterial activity of plant volatile oils. Applied Microbiology, 88, 308-316. https://doi.org/10.1046/j.1365-2672.2000.00969.x

Darwish, R., \& Aburjai, A.T. (2010). Effect of ethnomedicinal plants used in folklore medicine in Jordan as antibiotic resistant inhibitors on Escherichia coli. BMC Complementary and Alternative Medicine, 1-8. https://doi.org/10.1186/1472-6882-10-9

Davidson, P.M. (1997). Chemical Preservatives and Natural antimicrobia compounds. In Food Microbiology Fundamentals and Frontiers, Doyle, M.P., Beuchat, L.R., Montville, T.J. (eds), pp. 520-556, NY: ASM Press.

El bashiti, T.A., Elmanama, A.A., \& Masad, A.A. (2011). The antibacterial and synergistic effects of some Palestinian plant extracts on Escherichia coli and Staphylococcus aureus. Functional Plant Science and Biotechnology, 5, 57-62. https://doi.org/10.47059/alinteri/v35i2/ajas20086

El Mokni, R., Majdoub, S., Jlassi, I., Joshi, R.K., \& Hammami, S. (2020). Gas chromatography-mass spectrometry profile and antimicrobial activities of Ballota bullata Pomel and B. nigra L. subsp. uncinata (Fiori \& Bég.): A comparative analysis. International Journal of Mass Spectrometry. https://doi.org/10.1016/j.ijms.2020.116305.

Enne, V.I., Livermore, D.M., Stephens, P., \& Hal, L.M.C. (2001). Persistence of sulphonamide resistance in Escherichia coli in the UK despite national prescribing restriction. The Lancet, 28,

$1325-$

1328. https://doi.org/10.1016/s0140-6736(00)04519-0

Esmael, M.G., Hassan, M.M., Amer, S., Abdelrahman, A.M., Hamed, H.A., \& Abd-raboh, M.F. (2019). Antimicrobial activity of certain natural-based plant oils against the antibiotic-resistant Acne bacteria. Saudi Journal of Biological Sciences. https://doi.org/10.1016/j.sjbs.2019.11.006

El Ouadi, Y., Manssouri, M., Bouyanzer, A., Majidi, L., Bendaif, H., Elmsellem, H., Shariati, M.A., Melhaoui, A., \& Hammouti, B. (2017). Essential oil composition and antifungal activity of Melissa officinalis originating from NorthEst Morocco, against postharvest phytopathogenic fungi in apples. Microbial Pathogenesis, 107, 321-326. https://doi.org/10.1016/j.micpath.2017.04.004

Eruygur, N., Koçyiğit, U.M., Taslimi, P., Ataş, M., Tekin, M., \& Gülçin, I (2019). Screening the in vitro antioxidant, antimicrobial, anticholinesterase, antidiabetic activities of endemic Achillea cucullata (Asteraceae) ethanol extract Journal Article published Jan 2019 in South African Journal of Botany, 120, 141 to 145 https://doi.org/10.1016/j.sajb.2018.04.001

Evans, C.E., Banso, A., \& Samuel, O.A. (2002). Efficacy of some nupe medicinal plants against Salmonella typhi: an in vitro study. Journal of Ethno pharmacology, 80, 21-24. https://doi.org/10.1016/s0378-8741(01)00378-6

Friedman, M., \& Smith, G.A. (1984) Inactivation of quercetin mutagenicity. Food Chemistry \& Toxicology, 22, 535-539.

Farag, R.S., Daw, Z.Y, Hewedi, F.M., EL-Baroty, G.S.A (1989). Antimicrobial activity of some egyptian spice essential oils. Journal of Food Protection, 52, 665-667. https://doi.org/10.4315/0362-028x-52.9.665

Farnsworth, N.R., \& Loub, W.D. (1983). Information gathering and data bases that are pertinent to the development of plant-derived drugs in Plants: The Potentials for Extracting Protein, Medicines, and Other Useful Chemicals. Workshop Proceedings. OTA-BP-F-23. U.S. Congress, Office of Technology Assessment, Washington, D.C., pp. 178-195.

Gishen, N.Z., Taddese, S., Zenebe, T., Dires, K., Tedla, A., Mengiste, B., Shenkute, D., Tesema, A., Shiferaw, Y., \& Lulekal, E. (2020). In vitro antimicrobial activity of six Ethiopian medicinal plants against Staphylococcus aureus, Escherichia coli and Candida albicans. European Journal of Integrative Medicine, 36, 101121. https://doi.org/10.1016/j.eujim.2020.101121

Guadie, A., Dakone, D., Unbushe, D., Wang, A., \& Xia, S. (2020). Antibacterial activity of selected medicinal plants used by traditional healers in Genta Meyche (Southern Ethiopia) for the treatment of gastrointestinal disorders. Journal of Herbal Medicine. https://doi.org/10.1016/j.hermed.2020.100338

Hammer, K. A., Carson, C. F., \& Riley, T. V. (1999). Antimicrobial activity of essential oils and other plant extracts. Journal of Applied Microbiology, 86 (6) 985-990. https://doi.org/10.1046/j.1365-2672.1999.00780.x

Hleba L, Petrová J, Kordiak R, Kántor A, Čuboň J, Kluz M, Shariati MA, Kačániová M. Antibacterial Activity of Habanero Chili Sauces against Selected Pathogenic Bacteria. Scientific Papers: Animal Science and Biotechnologies, 2015, 48 (1).

Ilić, D. P., Stanojević, P.L., Troter, D.Z., Stanojević, J.Z., Danilović, B.R., \& Nikolić, B.D. Nikolić, B.L. (2019). Improvement of the yield and antimicrobial activity of fennel (Foeniculum vulgare Mill.) essential oil by fruit milling. $\begin{array}{llll}\text { Industrial Crops \& Products, } 142, & 111854\end{array}$ https://doi.org/10.1016/j.indcrop.2019.111854

Jahn, S.A.A., Musnad, H.A., \& Burgstaller,H. (1986).The tree that purifies water: Cultivating multipurpose Moringaceae in the Sudan. Unasylva, 152, 23 28.

Janovska, D., Kubikova, K., \& Kokoska, L. (2003): Screening for antimicrobial activity of some medicinal plant species of traditional Chinese medicine. Czech Journal of Food Science, 21, 107-111. https://doi.org/10.17221/3485-cjfs

Jabeen, R., Shahid, M., Jamil, A., Ashraf, M. (2008). Microscopic evaluation of the antimicrobial activity of seed extracts of Moringa oleifera. Pakistan Journal of Botany, 40(4), 1349-1358.

Joseph B, Dar MA, Kumar V. Bioefficacy of plant extracts to control Fusarium solani F. sp. melongenae incitant of brinjal wilt. Global J Biotech Biochem. 2008:3(2):56-59.

Khouchlaa, A., El Menyiy, N., Guaouguaou, F.-E., El Baaboua, A., Charfi, S., Lakhdar, F., El Omari, N., Taha, D., Shariati, M.A., Rebezov, M., El-Shazly, M., \& Bouyahya, A. (2021) Ethnomedicinal use, phytochemistry, pharmacology, and toxicology of Daphne gnidium: A review. Journal of Ethnopharmacology, 275, 114124. https://doi.org/10.1016/j.jep.2021.114124

Kibwage O., Mwangi, J. W., \& Thoithi G. N. (2006). Quality control of herbal medicines. East and Central African Journal of Pharmaceutical Sciences, 8 (2), 27-30. https://doi.org/10.4314/ecajps.v8i2.9721

Kim, H., Park, S.W., Park, J.M., Moon, K.H., Lee, C.K. (1995). Screening and isolation of antibiotic resistance inhibitors from herb material Resistant Inhibition of 21 Korean plants. Natural Product Science, 1, 50 - 54 https://doi.org/10.1007/bf03216754

Kumar, S., \& Pandey, A.K. (2013). Chemistry and Biological Activities of Flavonoids: An Overview. The Scientific World Journal, 2013, Article ID 162750, 16 pages. http://dx.doi.org/10.1155/2013/162750

Kosti'c A.Ž., Milin 'ci'c, D.M., Bara'c, M.B., Shariati, M.A., Teši'c, Z.L., \& Peši'c, M.B. (2020). The Application of Pollen as a Functional Food and Feed 
Ingredient-The Present and Perspectives. Biomolecules, 10 84. https://doi.org/10.3390/biom10010084

Kubo, I., Matsumoto, A., \& Takase, I. (1985). A multichemical defense mechanism of bitter olive Olea europaea (Oleaceae). Is oleuropein a phytoalexin precursor? Journal of Chemical Ecology, 11(2), 251-263. https://doi.org/10.1007/bf00988207

Laila, U., Akram, M., Shariati, M.A., Hashmi, A.M., Akhtar, N., Tahir, I.M., Ghauri, A.O., Munir, N., Riaz, M., Akhter, N., Shaheen, G., Ullah, Q., Zahid, R., \& Ahmad, S. (2019). Role of medicinal plants in HIV/AIDS therapy. Clinical and Experimental Pharmacology and Physiology, 46(12), 1063-1073. https://doi.org/10.1111/1440-1681.13151

Lopez, A., Hudson, J.B., \& Towers, G.H. (2001). Antiviral and antimicrobia activities of colombian medicinal plants. Journal of Ethnopharmacology, 77(23), 189-196. https://doi.org/10.1016/s0378-8741(01)00292-6

Lachowicz, K.J., Jones, G.P., Briggs, D.R., Bienvenu, F.E., Wan, J., Wilcock, A \& Coventry, M.J. (1998). The synergistic preservative effects of the essential oils of sweet basil (Ocimum basillicum L.) against acid-tolerant food microflora. Letters in Applied Microbiology, 26, 209-214. https://doi.org/10.1046/j.1472 765x.1998.00321.x

Lambert, R.J.W., \& Pearson, J. (2000). Susceptibility testing: accurate and reproducible minimum inhibitory concentration (MIC) and non-inhibitory concentration (NIC)values. Journal of Applied Microbiology, 88, 784-790. https://doi.org/10.1046/j.1365-2672.2000.01017.x

Martino, P.D., Gagniere, H., Berry, H., \& Bret, L. (2002). Antibiotic resistance and virulence properties of Pseudomonas aeruginosa strains from mechanically ventilated patients with pneumonia in intensive care units: comparison with imipenem-resistant extra-respiratory tract isolates from uninfected patient Microbes and Infection, 613- 620. https://doi.org/10.1016/s1286-4579(02)015794

Mathekaga, A.D., Meyer, J.J.M. (1998). Antibacterial activity of South African Helichrysum species. South African Journal of Botany, 64 (5), 293-295. https://doi.org/10.1016/s0254-6299(15)30903-0

Mann, C.M., \& Markham, J.L. (1998). A new method for determining the minimum inhibition concentration of essential oils. Journal of Applied Microbiology, 84, 538- 544. https://doi.org/10.1046/j.1365-2672.1998.00379.x

Mann, C.M, Cox, S.D., \& Markham, J.L. (2000). The outer mebrane of Pseudomonas aeruginosa NCTC 6749 contributes to its tolerance to the essential oil of Melaleuca alternifolia (tea tree oil). Letters in Applied Microbiology, 30, 294-297. https://doi.org/10.1046/j.1472-765x.2000.00712.x

Manou, L., Bouillard, L., Devleeschouwer, M.J., \& Barel, A.O. (1998) Evaluation of the preservative properties of Thymus vulgaris essential oil in topically applied Moken, M.C., Mcmurry, L.M., \& Levy, S.B. (1997) Selection of multiple-antibiotic resistant (mar) mutants of Escherichia coli by using the disifectant pine oil: roles of the mar and acrABloci. Antimicrobial Agents and Chemotherapy, 41, 2770-2772. https://doi.org/10.1128/aac.41.12.2770.

Maria Braga Ribeiro, A., de Sousa, J.N., Muratori Costa, L., de Alcântara Oliveirab, F.A., dos Santos, R.C., Silva Nunes, A.S., da Silva, W.O., Marques Cordeiro, P.J., Lima Neto, J.D.S., de Siqueira-Júnior, J.P., William Kaatz, G., Medeiros Barreto, H., \& de Oliveira, A.P. (2019). Antimicrobial activity of Phyllanthus amarus Schumach. \& Thonn and inhibition of the NorA efflux pump of Staphylococcus aureus by Phyllanthin. Microbial Pathogenesis, 130, 242246. https://doi.org/10.1016/j.micpath.2019.03.012

Mishra, A.P., Sharifi-Rad, M., Shariati, M.A., Mabkhot, Y.N., Al-Showiman, S.S., Rauf, A., Salehi, B., Župunski, M., Sharifi-Rad, M., Poonam, G., SharifiRad, J., Rasul Suleria, H.A., \& Iriti, M. (2018). Bioactive compounds and health benefits of edible Rumex species-A review. Cellular and Molecular Biology, 64 (8), 27-34 https://doi.org/10.14715/cmb/2018.64.8.5

Mejlholm, O., Dalgaard, P. (2002). Antimicrobial effect of essential oils on the seafood spoilage microorganism Photobacterium phospho reum in liquid media and fish products. Applied Microbiology, 34, 27-31. https://doi.org/10.1046/j.1472-765x.2002.01033.x

formulations under a challenge test. Journal of Applied Microbiology, 84, 368376. https://doi.org/10.1046/j.1365-2672.1998.00353.x.

Mukherjee, P.W. (2002). Quality Control of Herbal Drugs: An Approach to Evaluation of Botanicals. New Delhi, India: Business Horizons Publishers.

Nweze, E.L., Okafor, J.I., \& Njokn, O. (2004). Antimicrobial activities of methanolic extracts of Trema guinensis (Schumm and Thorn) and Morinda lucida Benth used in Nigeria. Biological Research, 2, 3946. https://doi.org/10.4314/br.v2i1.28540

Naczk, M., \& Shahidi, F. (2006). Phenolics in cereals, fruits and vegetables: occurrence, extraction and analysis. Journal of Pharmaceutical and Biomedical Analysis, 41 (5), 1523-1542. https://doi.org/10.1016/j.jpba.2006.04.002

Opal, S.M., Mayer, K., \& Medeiros, A. (2000). in Mechanisms of Bacterial Antibiotic Resistance. Principles and Practice of Infectiousiseases 5th ed. Ch. 16 (eds. Mandell, G. L., Bennett, J. \& Dolin, R.). Churchill Livingstone, Philadelphia, USA. 236-253.

Oyedeji-Amusa, M.O, \& Ashafa A.O.T. (2019). Medicinal properties of whole fruit extracts of Nauclea latifolia Smith.: Antimicrobial, antioxidant and hypoglycemic assessments. South African Journal of Botany, 121, 105-113 https://doi.org/10.1016/j.sajb.2018.11.001
Ozcan, K., Acet, T., Corbac1, C., \& Centaurea hypoleuca, D.C. (2019). Phenolic content, antimicrobial, antioxidant and enzyme inhibitory activities. South African Journal of Botany, 127, 313_318. https://doi.org/10.1016/j.sajb.2019.10.020

Paswan, S.K., Srivastava, S., \& Rao, C.V. (2020). Wound healing, antimicrobial and antioxidant efficacy of Amaranthus spinosus ethanolic extract on rats. Biocatalysis and Aricultural Biotechnology. https://doi.org/10.1016/j.bcab.2020.101624.

Patte, J. (1996). Biosynthesis of threonine and lysine. In Escherichia coli and Salmonella, Frederci M. and Neidhardt F. (eds), 2nd Edition, pp. 528-541. ASM Press, Washington DC.

Pattnaik, S., Rath, C., \& Subramanyam, V.R. (1995a). Characterization of resistance to essential oils in a strain of Pseudomonas aeruginosa (VR-6). Microbios, 81, (326) 29-31.

Pattnaik, S., Subrananyam, V.R., \& Rath, C.C. (1995b). Effect of essential oils on the viability and morphology of Escherichia coli (SP-11). Microbios, 84, 195 199.

Pattnaik, S., Subramanyam, V.R., Kole, C.R., \& Sahoo, S. (1995c). Antibacteial activity of essential oils from Cymbopogon: inter- and intra-specific differences. Microbios, 84 (341), 239-245.

Pavithra, P.S., Janani, V.S., Charumathi, K.H., Indumathy, R., Potala, S., \& Verma, R. S. (2010). Antibacterial activity of the plant used in Indian herba medicine. International Journal of Green Pharmacology, 10, 22-28. https://doi.org/10.4103/0973-8258.62161

Pirzadeh, M., Caporaso, N., Rauf, A., Shariati, M.A., Yessimbekov, Z., Khan, M.U., Imran, M., \& Mubarak, M.S. (2020): Pomegranate as a source of bioactive constituents: a review on their characterization, properties and applications. Critical Reviews in Food Science and Nutrition, 61 (6), 982-999, https://doi.org/10.1080/10408398.2020.1749825

Pitchai, D., Manikkam, R., Rajendran, S.R. (2010). Database on pharmacophore analysis of active principles from medicinal plants. Bioinformation, 5 (2), 43-45. https://doi.org/10.6026/9732063000543

Preethi, R., Devanathan, V.V., \& Loganathan, M. (2010). Antimicrobial and Antioxidant Efficacy of Some Medicinal Plants against Food Borne Pathogens Advances in Biological Research, 4 (2), 122-125.

Prindle, R.F., \& Wright, E.S. (1977) Phenolic compounds. In Disinfection, Sterilisation \& Preservation, Block, S.S. (ed.),. Lea \& Febiger, Philadelphia, pp. $219-251$

Rauf, A., Abu-Izneid, T., Rashid, U., Alhumaydhi, F.A., Bawazeer, S., Khalil, A.A., Aljohani, A.S.M., Abdallah, E.M., Al-Tawaha, A.R., Mabkhot, Y.N., Shariati, M.A., Plygun, S., Uddin, M., \& Ntsefong, G. N. (2020). Antiinflammatory, Antibacterial, Toxicological Profile, and in Silico Studies of Dimeric Naphthoquinones from Diospyros lotus. Biomed Research International, Article ID 7942549. https://doi.org/10.1155/2020/7942549

Santosa, J.D.C., Coelho, E., Silva, R., Passos, C.P., Teixeira, P., Henriques, H., \& Coimbra, M.A. (2019). Chemical composition and antimicrobial activity of Satureja montana byproducts essential oils. Industrial Crops \& Products, 137, 541-548. https://doi.org/10.1016/j.indcrop.2019.05.058

Shahidi Bonjar, G.H., \& Farrokhi, P.R. (2004). Antibacillus activity of some plants used in traditional medicine of Iran. Nigerian Journal of Natural Products and Medicine, 8(6), 34-39. https://doi.org/10.4314/njnpm.v8i1.11811

Sharma, A. (2011). Antibacterial activity of ethanolic extracts of some arid zone plants. International Journal of Pharmacological Technology Research, 3(1), 283-286.

Shakya, A.K., \& Shukla, S. (2011). Evaluation of hepatoprotective efficacy of Majoon-e-Dabeed-ul-ward against acetaminophen induced liver damage: A Unani herbal formulation. Drug Development Research, 72(4), 346-352. https://doi.org/10.1002/ddr.20436

Sharma, N., Kumar, V., Chopra, M.P., Sourirajan, A., \& Dev, K. (2020) Thalictrum foliolosum: A lesser unexplored medicinal herb from the himalayan region as a source of valuable phytocompounds, Journal of Ethnopharmacology. doi: https://doi.org/10.1016/i.jep.2020.112736

Shinwari, Z.K., \& Qaisar, M. (2011). Efforts on conservation and sustainable use of medicinal plants of Pakistan. Pakistan Journal of Botany, 43, 5-10.

Shityakov, S., Bigdelian, E., Hussein, A.A., Hussain, M.B., Chndra Tripathi, Y. Khan, M.U., \& Shariati, M.A. (2019). Phytochemical and pharmacological attributes of piperine: A bioactive ingredient of black pepper. European Journal $\begin{array}{llll}\text { of Medicinal } & \text { Chemistry, } & 176, & 149-161\end{array}$ https://doi.org/10.1016/j.ejmech.2019.04.002

Sieradzki, K., Wu, S.W., \& Tomasz, A. (1999). Inactivation of the methicillin resistance gene mecA in vancomycin-resistant Staphylococcus aureus. Microbial Drug Resistance, 5(4), 253-257. https://doi.org/10.1089/mdr.1999.5.253

Silver, L.L. (1993). Discovery and development of new antibiotics: the problem of antibiotic resistance. Antimicrobial Agents and Chemotherapy, 37, 377-383. https://doi.org/10.1128/aac.37.3.377

Shelef, L.A (1983) Antimicrobial effects of spices. Journal of Food Safety, 6 , 29-44. https://doi.org/10.1111/j.1745-4565.1984.tb00477.x.

Shelef, L.A., Naglik, O.A., \& Bogen, D.W. (1980) Sensitivity of some common food-borne bacteria to the spices sage, rosemary and allspice. Journal of Food Science, 45, 1042-1044. https://doi.org/10.1111/j.1365-2621.1980.tb07508.x. 
Skandamis, P. N., \& Nychas, G.-J.E. (2000). Development and evaluation of a model predicting the survival of Escherichia coli O157:H7 NCTC 12900 in homemade eggplant salad at various temperatures, $\mathrm{pH}$ and oregano essential oil concentrations. Applied and Environmental Microbiology. 66: 1646-1653. https://doi.org/10.1128/aem.66.4.1646-1653.2000

Soldati, F. (1997). The registration of medicinal plant products, what quality of documentation should be required? The industrial point of view," in Proceedings of the World Congress on Medicinal and Aromatic Plants for Human Welfare, Mendoza, Argentina, November 1997.

Srinivasana, R., Aruna, A., Manigandan, K., Pugazhendhi, A., Kima, M., Shivakumare, M.S., \& Natarajane, D. (2019). Phytochemical, antioxidant, antimicrobial and antiproliferative potential of Elaeagnus indica. Biocatalysis $\begin{array}{llll}\text { and Agricultural Biotechnology, 20, } & 101265\end{array}$ https://doi.org/10.1016/j.bcab.2019.101265

Srivastava, J., Lambert, J., \& Vietmeyer, N. (1996). Medicinal plants: An expanding role in development," World Bank Technical Paper, 320.

Stary F., \& Hans, S. (1998). The National guides to medical herbs and plants Tiger Books, Int. Plc. UK.

Stecchini, M.L., Sarais, I., \& Giavedoni, P. (1993) Effect of essential oils on Aeromonas hydrophila in a culture medium and in cooked pork. Journal of Food Protection, 56, 406-409. https://doi.org/10.4315/0362-028x-56.5.406

Stecchini, M.L., Del Torre, M., Sarais, I., Saro, O., Messina, M., \& Maltini, E. (1998). Influence of structural properties and kinetic constraints on Bacillus cereus growth. Applied and Environmental Microbiology, 64, 1075-1078 https://doi.org/10.1128/aem.64.3.1075-1078.1998.

Suffredini, B., Sader, H. S., \& Gonçalves, A. G. (2004). Screening of antibacterial extracts from plants native to the Brazilian amazon rain forest and atlantic forest. Brazilian Journal of Medical and Biological Research, 37(3), 379-384. https://doi.org/10.1590/s0100-879x2004000300015

Sultana, S., Munir, N., Mahmood, Z., Riaz, M., Akram, M., Rebezov, M. Kuderinova, N., Moldabayeva, Z., Shariati, M.A., Rauf, A., \& Rengasamy, K.R.R. (2021) Molecular targets for the management of cancer using Curcuma longa Linn. phytoconstituents: A Review. Biomedicine and Pharmacotherapy, 135, 111078. https://doi.org10.1016/j.biopha.2020.111078

Tassou, C., Drosinos, E. H., \& Nychas, G.-J.E. (1995). Effects of essentialoil from mint (Mentha piperita) on Salmonella enteritidis and Listeria monocytogenes in model food systems at $4^{\circ} \mathrm{C}$ and $10^{\circ} \mathrm{C}$. Journal of Applied Bacteriology, 78, 593-600. https://doi.org/10.1111/j.1365-2672.1995.tb03104.x . Tassou, C.C., Koutsoumanis, K., \& Nychas, G.-J.E. (2000) Inhibition of Salmonella enteritidis and Staphylococccus aureus in nutrient broth by mint essential oil. Food Research International, 33, 273-280. https://doi.org/10.1016/s0963-9969(00)00047-8.

Tian, H., Zhao, H., Zhoua, H., \& Zhang, Y. (2019). Chemical composition and antimicrobial activity of the essential oil from the aerial part of Dictamnus dasycarpus Turcz. Industrial Crops \& Products, 140, 111713. https://doi.org/10.1016/j.indcrop.2019.111713.

Torras-Claveria, L., Berkov, S., Codina, C., Viladomat, F., \& Bastida, J. (2014) Metabolomic analysis of bioactive Amaryllidaceae alkaloids of ornamental varieties of Narcissus by GC-MS combined with k-means cluster analysis. Industrial Crops and Products, 56, 211-222. https://doi.org/10.1016/j.indcrop.2014.03.008.

Ultee, A., \& Smid, E.J. (2001). Influence of carvacrol on growth and toxin production by Bacillus cereus. International Journal of Food Microbiology, 64, 373-378. https://doi.org/10.1016/s0168-1605(00)00480-3.

Vineela, C.H., \& Elizabeth, K.M. (2005). Antimicrobial activity of marine algae of Visakhapatnam city, Andhra Pradesh. Asian Journal Microbiology, Biotechnology and Environmental Sciences, 7, 209-212.

Welia, A.M., Al-Saadia, H.S., Al-Fudhaili, R.S., Hossain, A., Putit, Z.B., \& Jasim, M.K. (2020). Cytotoxic and antimicrobial potential of different leaves extracts of R. fruticosus used traditionally to treat diabetes. Toxicology Reports, 7, 183-187. https://doi.org/10.1016/j.toxrep.2020.01.006.

Westh, H., Zinn, C.S., \& Rosdahl, V.T. (2004). An international multicenter study of antimicrobial consumption and resistance in Staphylococcus aureus isolates from 15 hospitals in 14 countries. $\begin{array}{lllll}\text { Microbial Drug } & \text { Resistance, } & 10, & 169-176\end{array}$ https://doi.org/10.1089/1076629041310019.

Yina, L., Hana, H., Zhenga, X., Wanga, G., Lia, Y., \& Wang, W. (2019). Flavonoids analysis and antioxidant, antimicrobial, and anti-inflammatory activities of crude and purified extracts from Veronicastrum latifolium. Industrial Crops \& Products, 137, 652-661. https://doi.org/10.1016/j.indcrop.2019.04.007

Zaheer, J., Najam-Us-Saqib, Q., Anwar, T., Khan, F.S., Akram, M., Munir, N., Rebezov, M.,.Shariati, M.A., \& Thiruvengadam, M. (2021) Phytochemical Profile of Rock Jasmine (Androsace foliosa Duby ex Decne) by Using HPLC and GC-MS Analyses. Arabian Journal for Science and Engineering. https://doi.org/10.1007/s13369-020-05241-8 